\title{
YK:n ikääntymistä käsitellyt maailmankongressi
}

Yhdistyneiden Kansakuntien ikääntymistä käsitellyt maailmankongressi pidettiin Wienissä, Itävallassa 26.7.6.8.1982.

Mukana oli edustajia YK:n 124 jäsenvaltiosta, YK:n eri elimistä sekä YK:ssa neuvoaantavan aseman omaavista hallitustenvälisistä organisaatioista ja etujärjestöistä sekä myös useita huomioitsijoita.

Kokouksen päätarkoituksena oli käynnistää kansainväli- nen toimintaohjelma, jolla taattaisiin vanhoille ihmisille yhteiskunnallinen ja taloudellinen turva ja tarjottaisiin heille mahdollisuuksia antaa jatkuvasti oma panoksensa yhteiskuntansa kehittämiseen. 
Kokous kiinnitti huomiota 'ikääntyvien' väestöryhmien osuuden kasvuun. Korostuneesti tuli esiin, että maailmassa tulee vuoteen 2000 mennessä olemaan lähes 600 milj. yli kuusikymmenvuotiasta ihmistä ja että maapallon kaikilla alueilla tullaan kokemaan väestön ikääntymisilmiö. Tällaiseen arvioon antavat aihetta eliniän kohoaminen ja syntyvyyden väheneminen.

\section{Kansainvälinen toimintaohjelma}

Kokouksen merkittävin komitea käsitteli seuraavia ikääntymistä ja kehitystä koskevia asioita: a) kehityskysymykset suhteessa ikääntyvien yhteiskunnalliseen osallistumiseen ja ikääntyvien rooli kehitysprosessissa; ja b) humanitaariset, ikääntyvän yksilön erityistarpeisiin liittyvät kysymykset, jotka koskevat esim. terveydenhuoltoa, sosiaalipalveluja, asumista, kasvatusta ja perhettä.

Työskentelynsä lopuksi konferenssi hyväksyi kansainvälisen toimintaohjelman, johon sisältyvät seuraavat tavoitteet:

ohjelma pyrkii a) edistämään niiden taloudellisten, yhteiskunnallisten ja kulttuurillisten vaikutusten kansallista ja kansainvälistä ymmärtämistä, mitä väestön ikääntymisellä on suhteessa kehitysprosesseihin:

b) edistämään ikääntymiseen liittyvien humanitaaristen ja kehityskysymysten ymmärtämistä kansallisella ja kansainvälisellä tasolla;

c) ehdottamaan ja kannustamaan toiminnallisesti suuntautuvien periaatteiden ja ohjelmien toteuttamista, jotka pyrkivät takaamaan vanhoille ihmisille yhteiskunnallisen ja taloudellisen turvan ja antamaan heille mahdollisuuksia myötävaikuttaa kehitykseen ja jakaa sen mukanaantuomia etuja;

d) esittämään sellaisia vaihtoehtoisia väestön ikääntymistä ja vanhojen ihmisten tarpeita koskevia menettelytapoja ja vaihtoehtoisia ratkaisuja, jotka ovat sopusoinnussa sekä kansallisten arvojen ja päämäärien että kansainvälisesti hyväksyttyjen periaatteiden kanssa;

e) rohkaisemaan maailman väestön ikääntymisen kannalta tarkoituksenmukaisen kasvatuksen, koulutuksen ja tutkimuksen aikaansaamista ja edistämään alan kansainvälistä tietojen ja taitojen vaihtoa.

Toimintaohjelmaan sisältyneistä 48 suosituksesta 12 käsittelee nimenomaan kasvatusta ja koulutusta. Vanhojen ihmisten jatkuvan kasvatuksen tarve kytkettiin kokouksessa tieto- ja informaatioräjähdykseen, jonka vaikutuksesta myös vanhojen ihmisten tulisi päästä osallisiksi. Konferenssi suosittaa, että tulisi luoda sellaisia kasvatuksellisia ohjelmia, jotka näkevät ikääntyvät ihmiset opettajina ja tiedon, kulttuurin sekä henkisten arvojen välittäjinä.

Lähde: UNESCO Adult Education information notes No. 3/1982.

Vanhenemista on äskettäin käsitelty myös mm. seuraavissa julkaisuissa: The Unesco Courier, October 1982. The Fullness of Time. YK-tiedote 4/ 82. Harmaat pantterit.

News Letter, 1982-2, The European Bureau of Adult Education. Adult Education and Retirement. 